conditions may demand a considerable extension in our present methods of systematic arrangement, abstracting and indexing. In this connexion, two useful suggestions were made later in the discussion, by Mr. D. A. Bell and Dr. L. E. C. Hughes. The first was to the effect that it would prove very desirable to institute some kind of critical reports of progress in the various phases of radio technique, perhaps on the lines of the series of annual reports already issued by the Physical Society; while the second directed attention to the desirability, if not of the necessity, of using micro-film technique for the recording of published papers.

Messrs. V. Z. de Ferranti and C. E. Strong outlined the difficulties which are likely to confront a radio industry suddenly called upon to make a changeover from the carrying out of war contracts to Service specifications, to the re-establishment of a peace-time industry on a stable basis. It is clear that the present radio industry has not been planned on a sufficiently large scale, and it was suggested that this experience should be borne in mind in the future. At the termination of the present War, it is probable that the whole radio industry will require an interval in its production programme while the design and development of the new peace-time equipment is carried out. Some considerable foresight will be needed here to retain groups of staff and workers intact over a comparatively slack period before the industrial machine gets into its new stride.

Mr. J. A. Smale said that he anticipated many developments in the field of point-to-point radio telegraphic communications, including the use of printing telegraphs and coded messages. To a large extent the standards of transmission have been relaxed during the War, and it will be necessary to recover these if all the available channels are to be used in the most efficient manner. Mr. A. D. Blumlein expressed the somewhat comforting opinion that the methods of distributing television programmes used in 1939 were about right, and, apart from minor improvements, would need only slight revision to resume broadcast operation.

The probable directions in which the broadcast receiver industry is likely to resume activities were examined in some detail by Dr. R. C. G. Williams, who believes there is the possibility of some Government control of the industry as an outcome of a reconsideration of the political side of broadcasting. Both he and other speakers envisage the possibility of the use of an improved projection type of cathode ray tube for obtaining better picture reproduction in domestic receiving equipment.

After further contributions by other speakers, the discussion was brought to a close by Mr. H. Bishop, chairman of the Wireless Section of the Institution. It is desirable, he said, to plan a bold policy of expansion in the whole field of telecommunications, and this will of necessity involve dealing on a national basis with all the problems which have been brought forward, and particularly those of staff, education, and research and development. He referred to the difference in standards in television in the United States and in Great Britain, and agreed that our own system could quickly be ready for the resumption of a satisfactory public service. He also referred to the desirability of encouraging increased co-ordination in the field of post-war research, and expressed the hope that many secret devices developed under war conditions will be released for a peace-time application in due course for commercial purposes.

\section{THE FUTURE OF TECHNICAL EDUCATION*}

\author{
By H. J. CULL
}

TN common with all sections of the community, technical teachers find the progress of the War marked by increasing demands upon them. Apart from special courses, the average experience appears to be of a large increase in the part-time day classes of the colleges and the maintenance of evening or the substituted week-end classes at something approaching their normal level. To cater for these with, in many cases, depleted staffs has called for sacrifices of many of our cherished ideas as to conditions of service-changes in hours of duty per week, sizes of classes and suitability of accommodation for classes -which will demand the watchful care of the Association if they are to be regarded as temporary expedients and not precedents.

\section{Education and the Future}

Prominent in our thoughts in spite of many preoccupations is the discussion which has been in progress during the year on educational post-war reconstruction. Inspired in the first place by an official invitation by the Board of Education, the executive of the Association of Teachers in Technical Institutions, as well as similar groups within other major educational associations, has given consideration to this matter. Official pronouncements by succeeding presidents of the Board of Education, as well as provisions already on the statute book awaiting the announcement of "appointed dates" and also the wartime developments of activities among young people, make certain steps in reconstruction almost selfevident. It would appear, for example, that after the age of eleven plus, all schools should be secondary in character, equal in status, and administered by one department of the Board of Education. The main interest here of the Association is to secure the continuance as individual entities of those schools which have so fully justified themselves during recent years, namely, the junior technical schools. These schools, giving a broad general education; with a scientific approach to an industry as a whole; working in close association with the industry of the district; and provided with the equipment and the qualified staff to give the industrial bias, have achieved a success which cannot be questioned. The one handicap which has always been present and has had to be overcome has been the suggestion of inferiority due to the later age of entry when compared with other types of schools. If this be removed by the general reconstruction, we have no fear that the schools will produce youths who will be other than a credit to themselves and any society in which they are partners. Pioneers in this type of school are convinced of their value from the point of view of the studentnot alone of the industry which they join. The realistic approach to the studies means much to certain types of young people, and that is the real justification for wanting to preserve the schools and extend the experiment.

We are watching a development of adolescent education in two distinct directions at the moment. Firms are releasing for part-time day education employees in larger numbers than ever before.

* Substance of the presidential address delivered before the Associa tion of Teachers in Technical Institutions on May 23. 
Tribute must be paid to those firms who have thus met the difficulties of the youths in continuing their technical studies. It is believed that this war-time experience will persuade many firms of the value of this education, to their employees and to themselves, and that it will grow on a voluntary basis from year to year. Nevertheless we feel that part-time release should be made obligatory from the statutory age for full-time education, up to the age of eighteen. Much of such part-time work would be vocational in character and would be centred around the technical college.

Youth service is being officially sponsored in Great Britain for the first time. If part-time release for educational work is part of the reconstruction scheme, there must grow up in most districts a new type of school, already tried in a few areas, namely, the day continuation schools. This new youth service would in many cases seem to fuse with the work of the day continuation school. At the moment, the youth activity is bound to be war-biased, but one can hope that the aim of the combined day continuation school and youth activity will be to develop that complete personality inherent in us all-involving physical well-being; a developed mind able to appreciate and express; and a spiritual entity able to appreciate beauty in many directions and to take part in its perpetuation. So we find a further problem facing us on the technical side. Our organization of the vocational needs must be such as will not debar the youth of our colleges from a goodly share in physical and humanitarian activities.

\section{Full-time Technical Education}

In general reconstruction, too, the technical teachers would expect to realize some of those projects for which they have pressed for many years. For example, technical colleges have a contribution to make to a developing society by a more widely developed system of full-time courses. These might be attended by students coming direct from other types of schools, but perhaps more frequently by suitable partly trained students securing release from industry for a period to complete a course of training. Many pronouncements are made in these days that university students benefit greatly if they preface their university studies by some period in employment. This would probably be even more true of fulltime work in technical colleges. Associated with this is the whole question of scholarships for these senior students in the colleges, which we have claimed as deserving of official attention for some years now. Regional co-ordination of the senior colleges is a further point which will need consideration in the complete scheme.

As we plan now for a post-war community we are largely groping in the dark. We do not know much of the conditions in which we shall find ourselves. For this reason we should refrain from being closely fettered by decisions. We believe victory will bring us a greater measure of freedom to develop as individuals and as members of an international commonwealth. The great aim should be that we as teachers shall be ready to seize our opportunities on behalf of the youth of the country and bring to them better fruition than ever before. Led by a president of the Board of Education of full cabinet rank and able to make demands as a right to a full share of the country's resources for education, we should be alive to every possibility of advance along the lines we have set. Perfect buildings, staffs large enough and well enough trained for the perfect schools, equipment worthy of the standard set will probably be acquired only slowly. But war-time training of youths has produced results which have not reflected the difficulties under which it has been carried out. Under peace conditions we need not wait for the perfect surroundings before starting to train youth to make the most of their personalities.

\section{Building and Agriculture}

Turning to more immediate problems, we find evidence of much that demands careful thought. The Board of Education has indicated the need for the development of junior technical schools for the building industry. No departments of our colleges have suffered more in the depletion of their work during war-time than those of building. Yet imagination does not need much scope to see the immediate importance of this industry after the War. The Association welcomes the suggested encouragement of these schools. It visualizes them as being schools of the type mentioned previously, presenting an approach-view of the industry as a whole. Such a training would lead to a definite apprenticeship and form part of the apprenticeship training. There is time to plan this as a complete scheme and a permanent one, and it should not develop as a rough preparation for immediate post-war needs only. The industry and the senior college building departments must be important partners in the plan.

Another aspect of technical education has been recently considered: that affecting agriculture. Though of course provided with its own unique difficulties, the needs of this industry for a scientific background to its studies is as great as any other.

\section{SCIENCE AND THE WAR EFFORT}

A "SCIENCE for Victory" Conference, organized A by the Southern Area Committee of the Association of Scientific Workers, was held at University College, Southampton, on May 17. The meeting attracted scientific and technical workers from a wide area of southern England. Mr. Alexander Orba (instructor in radio at University College) presided at the afternoon session, and opened the Conference; he said that this was the first representative gathering of seientific and technical workers to be held in the Southampton area, to discuss the organization of their affairs and represented an important step forward in the part to be played by scientific men in the life of such an industrial area.

The opening speaker was Mr. H. W. Steele-Bodger, past president of the National Veterinary Medical Association, who spoke of the part veterinary science can play in the war effort by increasing the production of such foodstuffs as meat and milk. He emphasized that agriculture is really the basic and fundamental science and must be kept alive and flourishing if the people are to be fed. A Survey Committee of the National Veterinary Medical Association produced a comprehensive scheme for the control of diseases of livestock, and after years of patient effort had persuaded the Ministry of Agriculture to adopt it. As a result, he was confident that milk production would be very materially increased by the winter of 1943 . In general, however, such progress is hampered by 